\title{
Two new South American species of Croton (Euphorbiaceae) and their phylogenetic affinities
}

\author{
by \\ Ricarda Riina ${ }^{1,2} \&$ Paul E. Berry ${ }^{1}$ \\ ${ }^{1}$ University of Michigan Herbarium and Department of Ecology and Evolutionary Biology, 3600 Varsity Drive, \\ Ann Arbor, MI 48108, USA. peberry@umich.edu \\ ${ }^{2}$ Real Jardín Botánico, CSIC, Plaza de Murillo 2, E-28014 Madrid, Spain. riina@umich.edu
}

\begin{abstract}
Riina, R. \& Berry, P.E. 2010. Two new South American species of Croton (Euphorbiaceae) and their phylogenetic affinities. Anales Jard. Bot. Madrid 67(1): 23-27.

Two rarely collected species of Croton from South America are described and illustrated. Croton chimboracensis P.E. Berry \& Riina is localized in western Andean Ecuador and is sister to Croton sect. Adenophyllum Griseb. Croton abonari Riina \& P.E. Berry is known from a single location in Amazonian Brazil; it resembles both C. sampatik Müll. Arg. and members of Croton sect. Cuneati (G.L. Webster) Riina \& P.E. Berry, but C. abonari can be easily distinguished from both groups by distinctive morphological characters.
\end{abstract}

Keywords: Amazon, Andes, Croton abonari, C. chimboracensis, Euphorbiaceae.

\section{Introduction}

As a result of recent and ongoing taxonomic and phylogenetic studies on Croton, our understanding of this large genus has increased substantially, especially in the Neotropics, where several new species have recently been described by our network of collaborators (Secco \& al., 2001, 2005; Riina \& al., 2007; Steinmann \& Martínez-Gordillo, 2007; Carneiro-Torres \& al., in press; Caruzo \& al., 2008; Cordeiro \& al., 2008; Lima \& Pirani, 2008; Medeiros \& al., 2009; Van Ee \& Berry, 2009; Riina \& al., 2010a, 2010b), and several more are currently in preparation. These new findings will not substantially change the number of species in the megadiverse genus Croton, since other published names are being synonymized at roughly the same rate (Caruzo \& Cordeiro, 2007; Lima \& Pirani, 2008; Van Ee \& Berry, 2009; Riina \& al., 2010b;

\section{Resumen}

Riina, R. \& Berry, P.E. 2010. Dos nuevas especies suramericanas de Croton (Euphorbiaceae) y sus afinidades filogenéticas. Anales Jard. Bot. Madrid 67(1): 23-27 (en inglés).

Se describen e ilustran dos especies raras de Croton de Suramérica. Croton chimboracensis P.E. Berry \& Riina está localizada en los Andes occidentales de Ecuador y es hermana del clado de Croton sect. Adenophyllum Griseb. Croton abonari Riina \& P.E. Berry se conoce de una sola localidad en la Amazonia de Brasil; es similar tanto a C. sampatik Müll. Arg. y a miembros de la sección Cuneati (G.L. Webster) Riina \& P.E. Berry, pero C. abonari se puede diferenciar de ambos grupos por varios caracteres morfológicos distintivos.

Palabras clave: Amazonia, Andes, Croton abonari, C. chimboracensis, Euphorbiaceae.

Carneiro-Torres \& al., in press; Gomes \& al., in press). In this paper we describe two new species from South America that appear to be rare based on the few collections known to date, but are clearly distinct from any known species.

\section{Materials and methods}

We conducted a comparative morphological study of the new species using collections from several herbaria (GH, MICH, MO, NY, QCNE, US, WIS). Protologues and type specimens of similar Croton species were studied to clarify the delimitation of the new species. Standard morphological characters used by most previous taxonomic workers in Croton were used and described. All herbarium specimens were examined using a Olympus stereo microscope at $\times 64$ to $\times 400$ magnification. Information about 
habit, habitat, and distribution was taken from specimen labels.

\section{Results and discussion}

Croton chimboracensis P.E. Berry \& Riina, sp. nov.

Type: Ecuador. Chimborazo: Road from Alausí to Huigra, roadside thicket above Huigra, $02^{\circ} 16^{\prime} 28^{\prime \prime} \mathrm{S}$, 7858'23"W, 1380 m, 11-III-2001, P.E. Berry, J. Caranqui \& M. Cerna 7619 (holotype, MICH; isotypes, MO, QCNE, US, WIS). Figs. 1, 2.

Crotoni ruiziano similis, sed staminibus minoribus (12-14), apicibus columellae applanatis non laevigatis, trichomatibus stellato-porrectis differt.

Monoecious shrubs or small trees 1-5 m tall; young branches with a dense indumentum of stellate and multiradiate trichomes, producing a thick, orange sap when freshly cut. Stipules linear-lanceolate, 5-7 mm long, with a glandular tip, caducous. Leaves alternate, blades ovate to ovate-lanceolate, $5-12 \times 4-10 \mathrm{~cm}$, apex acute, base cordate or rounded, margin entire to finely

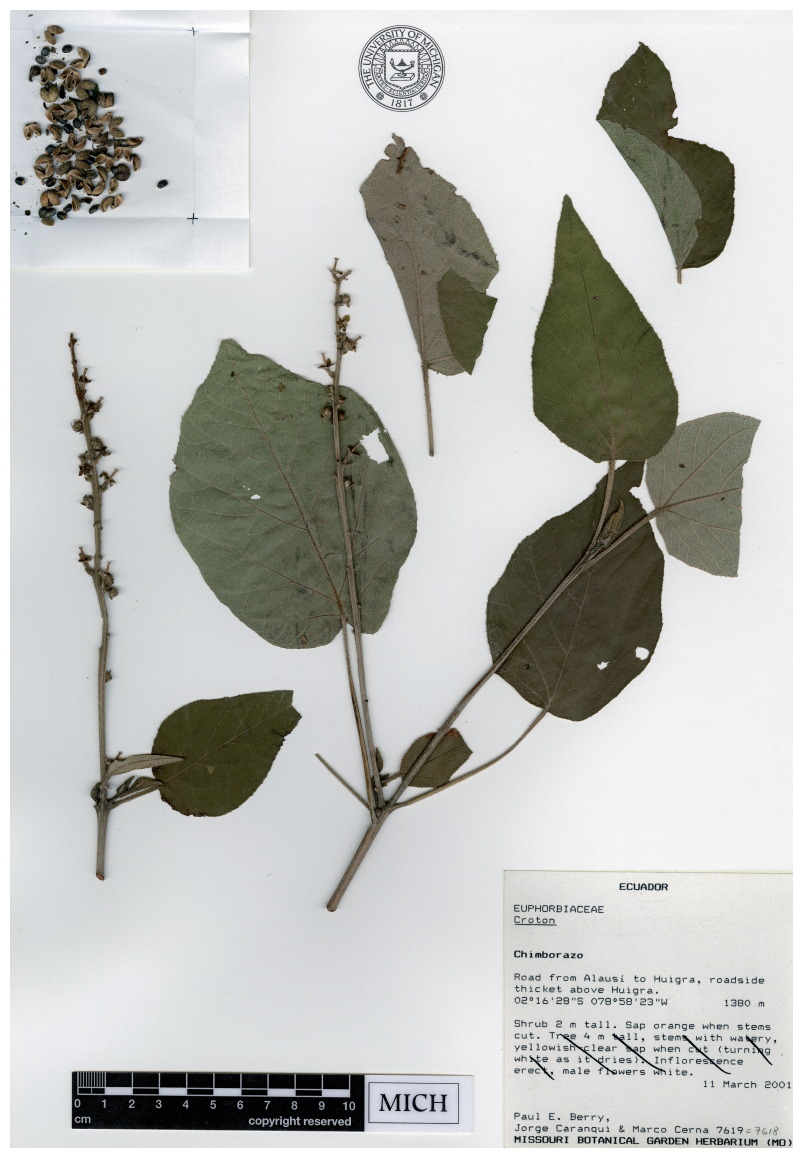

Fig. 1. Croton chimboracensis P.E. Berry \& Riina. Photo of the holotype, Berry \& al. 7619 (MICH).

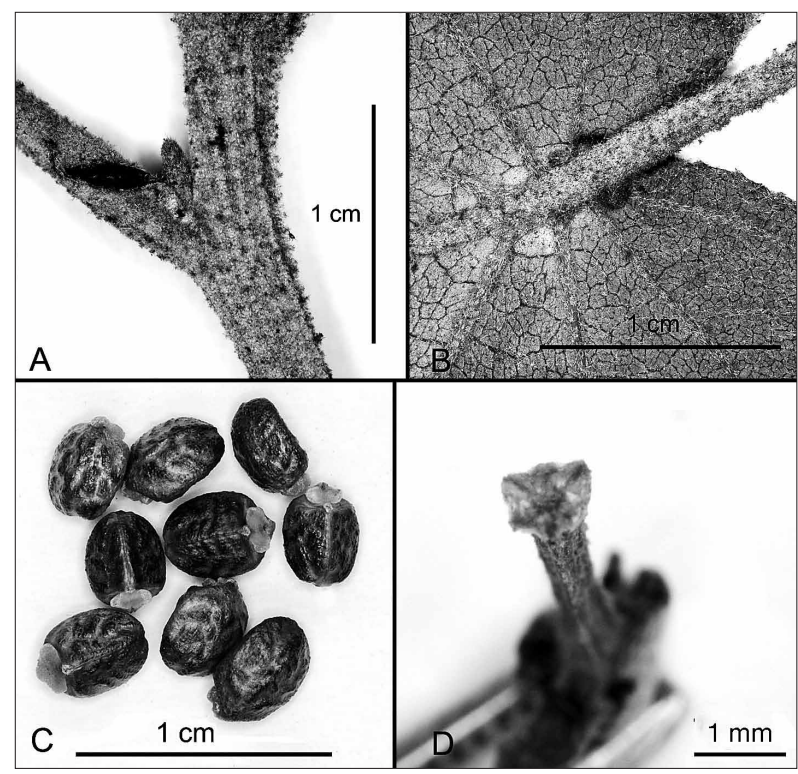

Fig. 2. Croton chimboracensis: A, stipule; B, petiolar glands, abaxial side of the leaf; $\mathbf{C}$, seeds; $\mathbf{D}$, distal end of the columella. Photos taken from the holotype.

serrate, venation 3-5-plinerved, secondary veins 5-7, tertiary veins scalariform, primary and secondary veins raised on the abaxial surface, adaxial leaf indumentum of scattered sessile stellate and multiradiate trichomes not fully covering the surface, which is green underneath the indumentum, abaxial indumentum denser, completely covering the surface; petiolar glands 2-4, patelliform, sessile or subsessile, acropetiolar, visible on the abaxial side; petioles $2.5-7 \mathrm{~cm}$ long, densely covered by multiradiate trichomes. Inflorescences terminal or pseudo-axillary, erect, $15-20 \mathrm{~cm}$ long, rachis angular, densely covered by multiradiate trichomes; bracts ovate-lanceolate, 1.8-4.0 × 0.7-2.0 mm, sometimes glandular at the tip, caducous; cymules evenly spaced along the rachis, the basal ones pistillate or sometimes bisexual. Staminate flowers in small cymules along distal $2 / 3$ of the rachis, pedicels $1-2 \mathrm{~mm}$ long at anthesis; sepals 5, imbricate, $1.5 \times 1 \mathrm{~mm}$, stellate abaxially, loosely villous adaxially; petals 5 , imbricate, elliptic-oblong, glabrous on both surfaces but densely white-villous along the margins; stamens $12-14$, filaments $2-3 \mathrm{~mm}$ long at anthesis, anthers $1 \times 1 \mathrm{~mm}$, ovalreniform. Pistillate flowers with pedicels 2-7 mm long, covered with sparse stellate and multiradiate trichomes; sepals 5, valvate to slightly imbricate, unequal, lanceolate to broadly ovate, $2-3 \times 1.5-2.5 \mathrm{~mm}$, abaxially with sparse stellate multiradiate trichomes concentrated on the central portion, adaxially glabrous; petals absent; ovary densely covered with multiradiate trichomes; styles 3, bifid (6 terminal tips), glabrous. 
Capsules globose, 5-7 × 6-7 mm; columella 5-6 mm long, the tips \pm flattened and rough; seeds obovoid, 3.8-4.9 $\times 3-3.1 \mathrm{~mm}$, light gray, brown or blackish, rugose, with a trapezoidal caruncle, $1.9 \times 1.5 \mathrm{~mm}$.

In the first molecular phylogeny of Croton by Berry $\&$ al. (2005), and in a later work (Cordeiro \& al., 2008), C. chimboracensis (which was listed as Croton sp. "Ecuador 7618") appeared in a position sister to all sampled members of $C$. sect. Cascarilla Griseb. (Fig. 3), now recognized as C. sect. Adenopbyllum Griseb. by van Ee \& Berry (2010). Riina \& al. (2009) identified the distal inflated lobes of the columella as a synapomorphy for this section (C. sect. Cascarilla in their work), but $C$. chimboracensis does not possess the characteristic inflated columella lobes of other members of the section, but more flattened lobes instead (Fig. 2D). Thus C. chimboracensis could repre- sent a novel section in the genus, but until we obtain a broader sampling of species in and around $C$. sect. Adenophyllum, we prefer to leave it unplaced as to section. The US sheet of Hitchcock 20386 was annotated by Leon Croizat in 1939 as C. ruizianus var. cordatus Müll.Arg., but that taxon belongs unambiguously to C. sect. Adenophyllum, with its shorter stature (0.5-1.5 m), smooth, inflated, 3-lobed columella, more numerous stamens (30-42), and stellateporrect trichomes. Based on van Ee \& Berry (2010) we use the name $C$. sect. Adenopbyllum Griseb. for what Webster (1993), Berry \& al., (2005) and Riina \& al. (2009) treated as C. sect. Cascarilla Griseb.

\section{Habitat and distribution}

Croton chimboracensis is known only from Chimborazo Province in the western Andes of Ecuador, and it is restricted to a small area above the town of

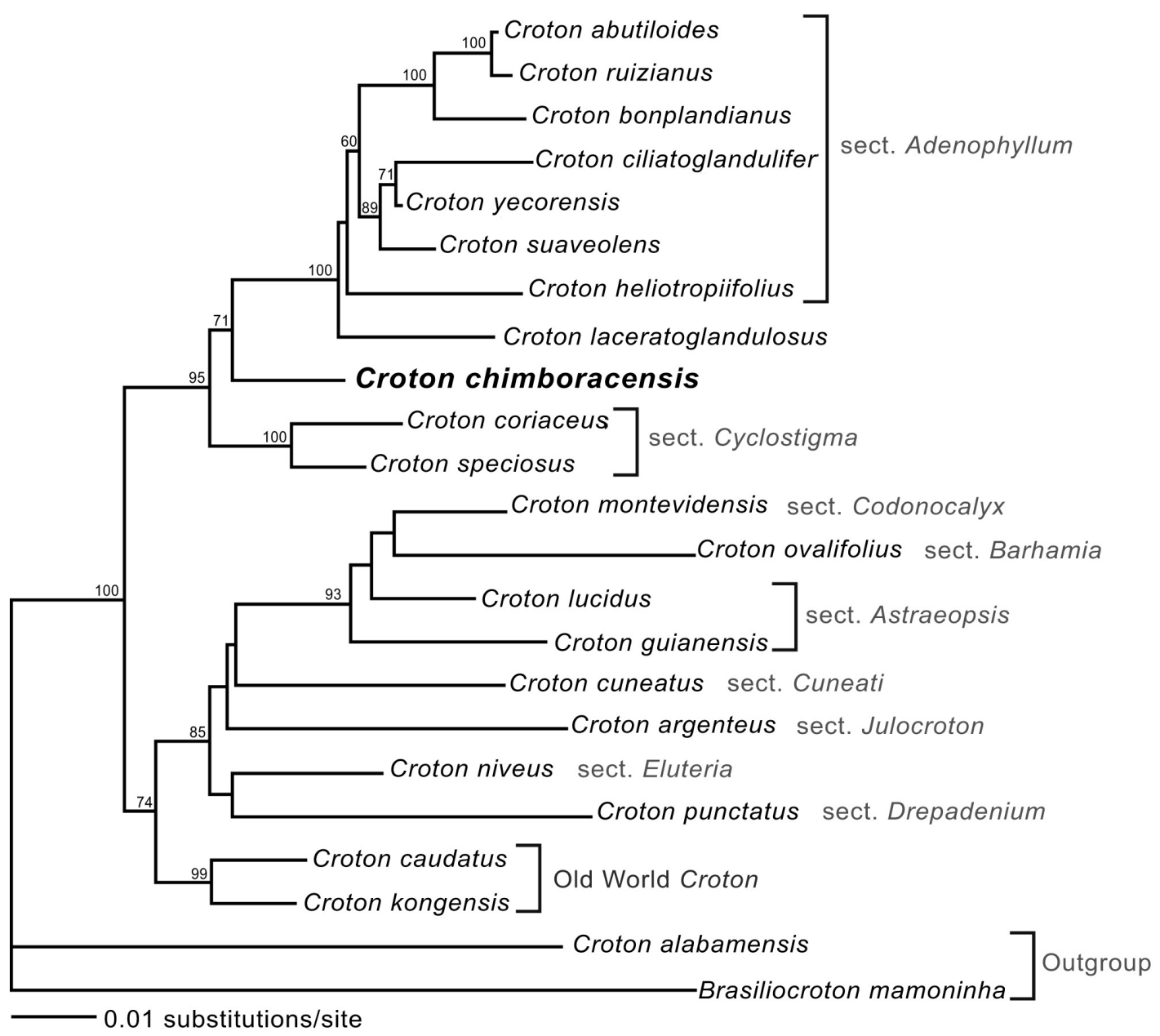

Fig. 3. Maximum likelihood phylogram of combined ITS and trnL-trnF data, showing the phylogenetic position of Croton chimboracensis (bold) sister to all sampled members of $C$. sect. Adenophyllum. Numbers above branches are parsimony bootstrap percentages. The labels on the right (gray) refer to sections of Croton. Figure modified from Cordeiro \& al. (2008) and reproduced here with permission from the Botanical Journal of the Linnean Society (Wiley-Blackwell). 
Huigra. The species grows in secondary woody vegetation along roadsides at 1200-2550 m elevation.

\section{Paratypes}

ECUADOR. Chimborazo: Road from Alausí to Huigra, roadside thicket above Huigra, 02 16 '28", 78 58'23'W, 1300 m, 11III-2001, P.E. Berry, J. Caranqui \& M. Cerna 7618 (MICH, MO, WIS); Cañon of Rio Chanchan near Huigra, 4000-4500 ft. elev., 714-V-1945, W.H. Camp E-3199 (MO, NY); Huigra, 1200 m, 4, 16, 20, 27-VII-1923, A.S. Hitchcock 20386 (GH, NY, US); Sibambe, canyon of Río Chanchan, 2460-2550 m, 28-I-1945, F.R. Fosberg \& M.A. Giler 22578 (US).

\section{Croton abonari Riina \& P.E. Berry, sp. nov.}

Type: Brazil. Amazonas: Santo Antonio de Abonari, Manaus-Caracarai, Km 220, forest on terra firme, 26-XI-1976, G.T. Prance, R.J. Hill, L.F. Coelho, J.F. Ramos 24311 (holotype: NY; isotypes, MICH, US). Figs. 4, 5.

Ad species sectionis Cuneati similis, sed glandulis petiolaribus adaxialibus, babitu non inundato differt.

Monoecious trees ca. $6 \mathrm{~m}$ tall and $8 \mathrm{~cm} \mathrm{DBH}$; young branches glabrescent, with scattered stellate-

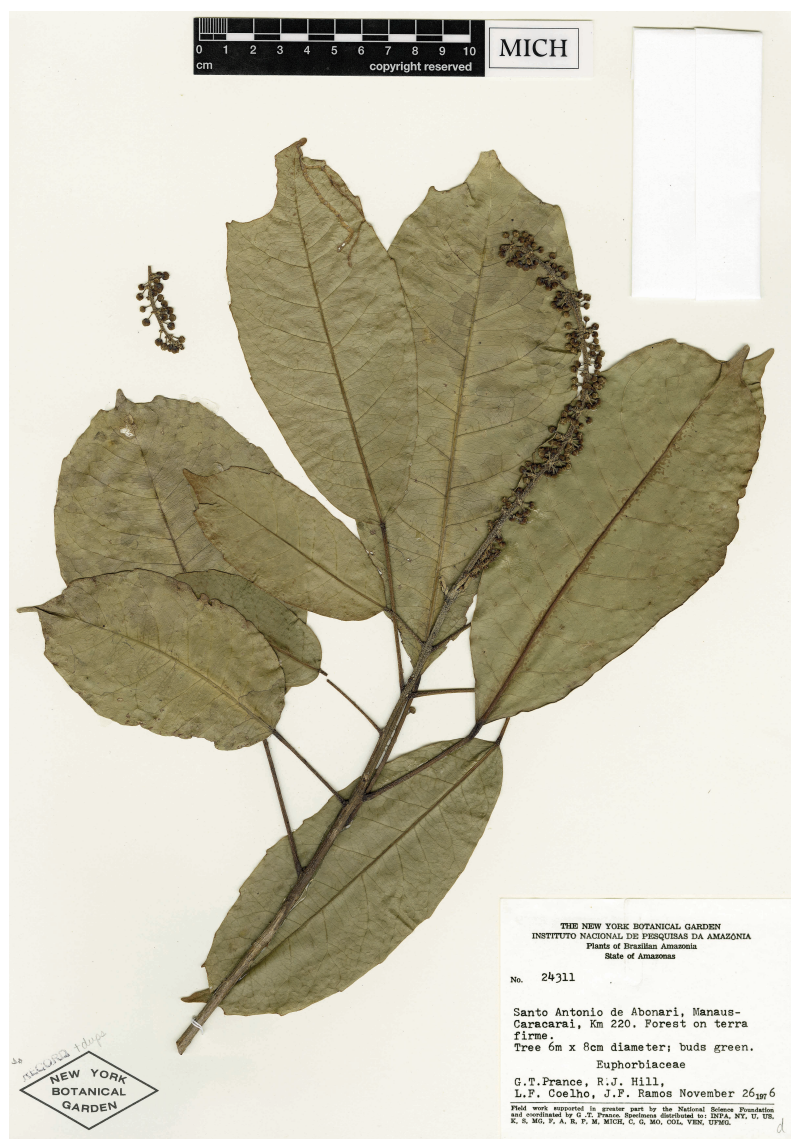

Fig. 4. Croton abonari Riina \& P.E. Berry. Photo of the holotype, Prance \& al. 24311 (NY).
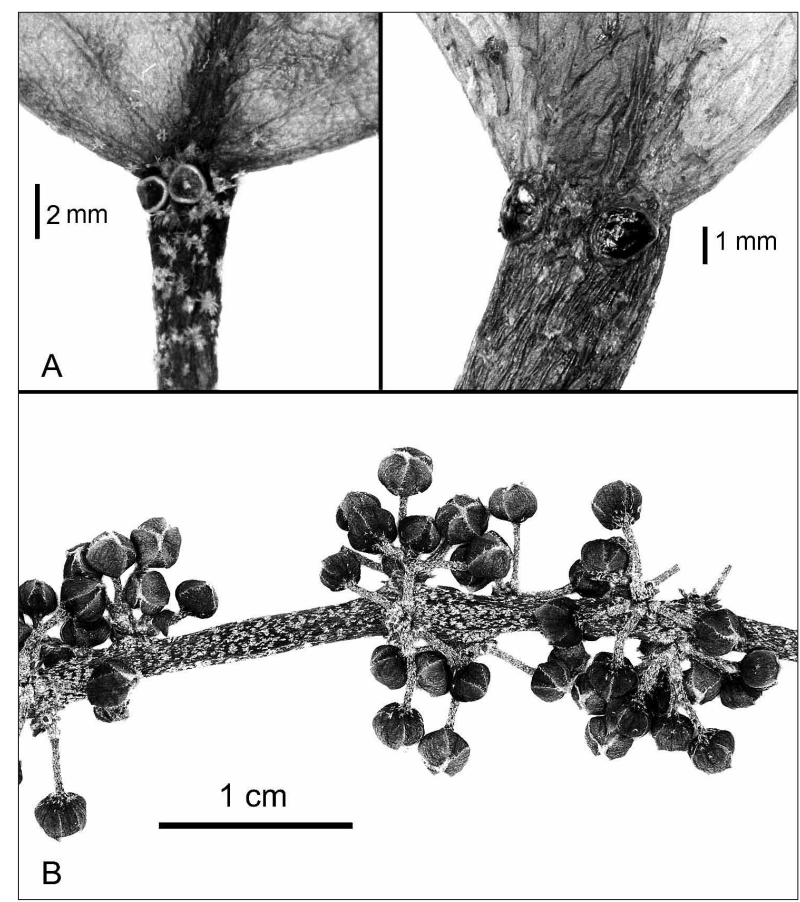

Fig. 5. Croton abonari: A, petiolar glands on a juvenile (left) and a mature leaf (right), adaxial leaf side; $\mathbf{B}$, detail of the inflorescence (flowers in bud). Photos taken from the holotype.

appressed or stellate-lepidote trichomes. Stipules deciduous. Leaves alternate, blades oblong-ovate, 8-20 $\times 4-8 \mathrm{~cm}$, apex cuspidate with an abrupt acuminate tip, base acute to rounded, margin irregularly and loosely dentate, with ovoid glands at the tip of each tooth and discoid sessile glands in the sinuses, both leaf surfaces glabrous or with very few stellate or stellate-lepidote trichomes on the main vein, lamina, or along the margins; venation pinnate, secondary veins 9-11, primary and secondary veins raised on abaxial and adaxial surfaces; petiolar glands patelliform, sessile, acropetiolar, positioned on the adaxial surface of the petiole; petioles $1.5-6.5 \mathrm{~cm}$ long, terete, sparsely stellate or appressed stellate-lepidote. Inflorescences terminal, usually clustered, erect, $15-18 \mathrm{~cm}$ long, rachis angular, densely stellate-multiradiate or appressed stellate-lepidote; bracts at the base of the inflorescence linear-lanceolate, $3-5 \times 0.9-1.1 \mathrm{~mm}$, cymule bracts variable in size and shape, from linear-lanceolate to broadly ovate with dentate margins; basal cymules bisexual. Staminate flowers numerous, 10-15, in dense cymules along most of the rachis, pedicels $2.3-4 \mathrm{~mm}$ long; sepals 5, valvate to slightly imbricate, broadly ovate to obovate (apical part wider), 2.9-3.2 × 1.8-2.1 $\mathrm{mm}$, glabrous on both surfaces, margin and apex pilose; petals 5 , narrowly ovate, $2-2.2 \times 0.8-0.9 \mathrm{~mm}$, glabrous on both surfaces, margin and apex lanate, re- 
ceptacle pilose, stamens 16 , filaments basally hirsute, $1.5-2 \mathrm{~mm}$ long (in bud), anthers 1.0-1.2 $\times 0.6-0.8 \mathrm{~mm}$. Pistillate flowers (in bud) subsessile; sepals 5, valvate to slightly imbricate; petals reduced to a filament with an apical gland; style branching uncertain (undeveloped in flower buds). Fruits and seeds unknown.

This new species has some characters in common with members of Croton sect. Cuneati (G.L. Webster) Riina \& P.E. Berry, such as the sinus glands on the leaf margin, stellate-lepidote trichomes, and the inflorescences in terminal or subterminal, apical clusters. Croton abonari differs from other members of C. sect. Cuneati in the adaxial position of the acropetiolar glands, which are usually abaxial in all the species of the section, in the cuspidate leaf apex, and in the much less dense indumentum on leaves and branches. Only one species in C. sect. Cuneati is glabrous, C. malambo, but it is restricted to dry coastal vegetation of northwestern Venezuela and northern Colombia. Unfortunately, the specimens of C. abonari lack seeds, which are morphologically quite distinct in species of $C$. sect. Cuneati (Riina \& al., 2010b). In addition, all lowland species of $C$. sect. Cuneati grow in riparian or flooded forests (except C. malambo), whereas C. abonari has been reported from low elevation terra firme forests. Croton abonari also resembles C. sampatik Müll. Arg., another Amazonian tree species in the Sampatik clade sensu Riina \& al. (2009), in features such as number of stamens (16), and the morphology and position of the petiolar glands. The two species differ in the type of marginal glands, which are stipitate in C. sampatik and sessile in C. abonari, and the leaf apex, which is cuspidate in $C$. abonari, and acute and not cuspidate in C. sampatik. Mature pistillate flo-wers, fruits and seeds, in addition to molecular data, will be needed to determine with confidence the phylogenetic position of C. abonari within the Neotropical members of Croton.

\section{Habitat and distribution}

Croton abonari is so far only known from the type locality in Amazonas State, Brazil, where it grows in terra firme forests (rainforests that are not inundated by flooded rivers).

\section{Acknowledgments}

We thank Bruno Manara for his revision of the Latin diagnoses and Jacquelyn Kallunki and Benjamin van Ee for their help in locating herbarium specimens at NY and GH. Heather Huggins (MICH) kindly scanned the herbarium specimens for the illustrations.

\section{References}

Berry, P.E., Hipp, A.L., Wurdack, K.J., Van Ee, B. \& Riina, R. 2005. Molecular phylogenetics of the giant genus Croton and tribe Crotoneae (Euphorbiaceae sensu stricto) using ITS and trnL-trnF DNA sequence data. American Journal of Botany 92: 1520-1534.

Carneiro-Torres, D., Cordeiro, I., Giulietti, A.M., Berry, P.E. \& Riina, R. In press. Three new species of Croton (Euphorbiaceae s.s.) from the Brazilian Caatinga. Brittonia.

Caruzo, M.B.R. \& Cordeiro, I. 2007. Sinopse da tribo Crotoneae Dumort. (Euphorbiaceae s.s.) no Estado de São Paulo, Brasil. Hoebnea 34(4): 571-585.

Caruzo, M.B.R., Riina, R., Cordeiro, I. \& Berry, P.E. 2008. Croton campanulatus (Euphorbiaceae s.s.), a new species from the Brazilian Atlantic rain forest. Brittonia 60: 261-264.

Cordeiro, I., Berry, P.E., Caruzo, M.B. \& van Ee, B. 2008. Croton laceratoglandulosus (Euphorbiaceae s.s.), a new glandularstipulate species from Brazil and Bolivia, and its systematic position based on molecular analysis. Botanical Journal of the Linnean Society 158: 493-498.

Gomes S., A.P., Sales F., M. \& Berry, P.E. In press. Croton limae (Euphorbiaceae), a new species of section Argyroglossum from northeastern Brazil. Brittonia.

Medeiros, D., Valle, L. de S., \& Valka Alves, R.J. 2009. Two new species of Croton L. (Euphorbiaceae) from campos rupestres of Minas Gerais State, Brazil. Journal of the Torrey Botanical Society 136: 186-191.

Lima, L.R. and Pirani, J.R. 2008. Three new species of Croton (Euphorbiaceae) from Brazil. Kew Bulletin 63: 121-129.

Riina, R., Cornejo, X. \& Berry, P.E. 2007. A new species of "sangre de drago" (Croton section Cyclostigma, Euphorbiaceae) from coastal Ecuador. Brittonia 59: 97-101.

Riina, R., Berry, P.E. \& Van Ee, B.W. 2009. Molecular phylogenetics of the dragon's blood Croton section Cyclostigma (Euphorbiaceae): a polyphyletic assemblage unraveled. Syst. Bot. 34: 360-374

Riina, R., Berry, P.E., Amorim, A. \& Cordeiro, I. 2010a. Croton thomasii Riina \& P.E. Berry (Euphorbiaceae), a new species from the Atlantic Fo-rest in the State of Bahia (Brazil) and typification of Croton sapiifolius Müll.Arg. Candollea (in press).

Riina, R., Van Ee, B., Wiedenhoeft, A.C., Cardozo, A. \& Berry, P.E. 2010b. Sectional rearrangement of arborescent clades of Croton (Euphorbiaceae) in South America: evolution of arillate seeds and a new species, Croton domatifer. Taxon (in press).

Secco, R.S., Berry, P.E., \& Rosa, N.A. 2001. Croton diasii and Croton trombetensis, two new Euphorbiaceae from Amazonian Brazil. Novon 11: 119-123.

Secco, R.D., Berry, P.E., \& Rosario, C.S. 2005. A new species of Croton sect. Luntia (Euphorbiaceae) from western Amazonian Brazil. Novon 15:583-585.

Steinmann, V.W. \& Martínez Gordillo, M. 2007. Croton balsensis (Euphorbiaceae), a new species from the Balsas Depression, Mexico. Brittonia 59: 380-384.

Van Ee, B.W. \& Berry, P.E. 2009. A Phylogenetic and taxonomic review of Croton (Euphorbiaceae s.s.) on Jamaica including the description of Croton jamaicensis, a new species of section Eluteria. Systematic Botany 34: 129-140.

Van Ee, B.W. \& Berry, P.E. 2010. Typification notes for Croton (Euphorbiaceae). Harvard Papers in Botany 15(1): (in press).

Webster, G.L. 1993. A provisional synopsis of the sections of the genus Croton (Euphorbiaceae). Taxon 42: 793-823.

Editor asociado: A. Susanna Recibido: 8-I-2010

Aceptado: 8-IV-2010 